\title{
Comparative proteomic analysis of the effect of temperature and fertilizer on gliadin and glutenin accumulation in the developing endosperm and flour from Triticum aestivum L. cv. Butte 86
}

\author{
William J Hurkman, Charlene K Tanaka, William H Vensel, Roger Thilmony and Susan B Altenbach*
}

\begin{abstract}
Background: Flour quality is largely determined by the gluten proteins, a complex mixture of proteins consisting of high molecular weight-glutenin subunits (HMW-GS), low molecular weight-glutenin subunits (LMW-GS), and a-, $\gamma^{-}$, and $\omega$-gliadins. Detailed proteomic analyses of the effects of fertilizer and high temperature on individual gliadin and glutenin protein levels are needed to determine how these environmental factors influence flour quality.

Results: Wheat plants (Triticum aestivum L. cv. Butte 86) were grown in greenhouses under moderate and high temperature regimens with and without post-anthesis fertilizer. Quantitative two-dimensional gel electrophoresis was used to construct accumulation profiles in developing endosperm for the entire complement of gluten proteins identified previously by tandem mass spectrometry. Amounts of individual gliadins and glutenins were also determined in flour produced under each of the regimens. Under all environmental regimens, most HMW-GS, LMW-GS, $\gamma$ - and $\omega$-gliadins accumulated rapidly during early stages of grain development and leveled off during middle stages of development. A subset of LMW-GS showed a second distinct profile, accumulating throughout development, while a-gliadins showed a variety of accumulation profiles. In flour, fourteen distinct gluten proteins responded similarly to fertilizer, high temperature, and high temperature plus fertilizer. The majority of HMW-GS and $\omega$-gliadins and some a-gliadins increased while two LMW-GS and a minor $\gamma$-gliadin decreased. Fertilizer did not influence gluten protein accumulation under high temperature conditions. Additionally, the effects of fertilizer and high temperature were not additive; very few changes were observed when plants that received fertilizer were subjected to high temperature.

Conclusions: Although post-anthesis temperature and fertilizer have very different effects on grain development and yield, the two treatments elicit surprisingly similar effects on the accumulation of gluten proteins. The similarity of the responses to the different treatments is likely due to source-sink activities of nitrogen reserves in the wheat plant. Because each protein that showed a response in this study is linked to a gene sequence, the work sets the stage for transgenic studies that will better elucidate the roles of specific proteins in flour quality and in the response to the environment.
\end{abstract}

Keywords: Endosperm, Fertilizer, Flour, Gliadins, Glutenins, Proteome, Temperature, Wheat

\footnotetext{
* Correspondence: susan.altenbach@ars.usda.gov

U.S. Department of Agriculture, Agricultural Research Service, Western

Regional Research Center, 800 Buchanan St, Albany, CA 94710, USA
} 


\section{Background}

Wheat flour is used worldwide as an ingredient in a variety of baked products due to its unique protein properties. When flour is mixed with water, the proteins interact to form gluten, a continuous protein network that is responsible for the viscoelastic properties and gas holding capacity of flour dough. Gluten is a complex mixture of several hundred proteins with molecular weights ranging from 30,000 to $88,000 \mathrm{Da}$. The gluten proteins are synthesized in the endosperm of the developing wheat grain and comprise $60-80 \%$ of flour protein. Based on extraction and solubility properties, the gluten proteins can be separated into two major groups: the alcohol-soluble gliadins and the alcoholinsoluble glutenins [1]. The gliadins contribute mainly to the viscosity and extensibility of wheat dough and the glutenins to elasticity and dough strength. The monomeric gliadins are classified as $\alpha_{-}^{-}, \gamma^{-}$, and $\omega$-gliadins based on their mobility in acid PAGE gels. The glutenins are classified as high molecular weight-glutenin subunits (HMW-GS) and low molecular weight-glutenin subunits (LMW-GS), which link together via intermolecular disulfide bonds to form large insoluble polymers. Variations in flour quality are related to genetic differences in gliadin and glutenin composition among wheat cultivars and to effects of environmental conditions on their relative proportions [2,3].

Since consistent flour quality is important to end users, an increased understanding of the effects of environment on individual gliadins and glutenins and their relationship to quality is needed. Due to the difficulties in separating individual gluten proteins by chromatographic methods [4], quantitative two-dimensional gel electrophoresis (2-DE) has become a method of choice for identifying proteins that respond to environmental cues. To date, a number of studies have used 2-DE to discover gluten protein responses to high temperature, fertilizer, or drought [5-11] and have reported changes in as few as three [8] to as many as 107 2-DE spots [11]. Mass spectrometry (MS) was used to identify some of the proteins that showed responses to environmental cues. However, in most studies, identifications were based on very few peptides and it was generally not possible to distinguish individual gluten proteins within the major classes.

Recently, we developed improved methods for tandem mass spectrometry (MS/MS) identification of the gluten proteins. Proteins in 2-DE spots were digested individually with chymotrypsin, thermolysin, and trypsin to increase sequence coverage. In addition, search strategies were improved and databases that included cultivarspecific gluten protein sequences were constructed for analysis of spectral data [12]. This methodology made it possible to develop a comprehensive proteome map of flour from the US wheat Butte 86 in which 233 individual 2-DE spots were assigned to specific gene sequences [13]. Gluten proteins identified included 5 HMW-GS, 22 LMW-GS, $13 \gamma$-gliadins, $23 \alpha$-gliadins and $4 \omega$-gliadins, many of which had sequence coverage greater than $50 \%$. Among the proteins identified in this study were $\alpha-, \gamma-$ and $\omega$-gliadins that contain extra cysteine residues and may be linked into the glutenin polymer. In addition, $\alpha-$ gliadins containing specific epitopes involved in celiac disease were distinguished from those that do not contain these sequences. The proteome map made possible a detailed analysis of the effects of fertilizer on gliadin and glutenin levels in flour [14]. One-hundred twentytwo gluten protein spots representing 19 gluten protein gene sequences responded significantly to fertilizer: five HMW-GS, six $\alpha$-gliadins, and four $\omega$-gliadins increased and three LMW-GS and one $\gamma$-gliadin decreased.

In this paper, we compare the effects of high temperature and fertilizer singly and in combination on the entire complement of gliadins and glutenins in developing endosperm and in flour from mature grain. The study extends earlier studies in which we analyzed the effects of high temperature and fertilizer on a limited number of gliadins and glutenins in developing endosperm by $2-\mathrm{DE}$ and evaluated flour composition by RPHPLC $[5,6]$. Because the Butte 86 proteome map links gluten proteins to gene sequences, the goal of this study was to identify genes encoding proteins that respond to fertilizer and high temperature that can be used in transgenic approaches to determine the roles of specific proteins in flour quality and in the response of the grain to environmental cues.

\section{Results}

High temperature and fertilizer alter fresh weight and gluten protein levels during grain development

The plant growth regimens used and the comparisons made in this study are summarized in Table 1 . All plants were grown at $24 / 17^{\circ} \mathrm{C}$ (day/night maximum temperatures) with fertilizer until anthesis, when pots were placed into

\section{Table 1 Key to plant growth regimens and expected} results

\begin{tabular}{ll}
\hline Regimen & Expected result \\
\hline$M^{1} v M F^{2}$ & Differences due to fertilizer under moderate temperature. \\
$M_{N v H N^{3}}$ & Differences due to high temperature. \\
$M N v H F^{4}$ & Differences due to high temperature plus fertilizer. \\
$M F v H F$ & $\begin{array}{l}\text { Differences due to high temperature in the presence of } \\
\text { fertilizer. }\end{array}$ \\
HNvHF & Differences due to fertilizer under high temperature.
\end{tabular}

\footnotetext{
${ }^{1} \mathrm{MN}$, moderate temperature without fertilizer.

${ }^{2} \mathrm{MF}$, moderate temperature with fertilizer.

${ }^{3} \mathrm{HN}$, high temperature without fertilizer.

${ }^{4} \mathrm{HF}$, high temperature with fertilizer.
} 
four groups. Two groups of plants were irrigated with fertilizer, but one group was grown at $24 / 17^{\circ} \mathrm{C}(\mathrm{MF}$, moderate temperature with fertilizer regimen) and the other at $37 / 28^{\circ} \mathrm{C}$ (HF, high temperature with fertilizer regimen). The remaining two groups of plants were flushed extensively with water to remove fertilizer. Both groups were watered without fertilizer; one group was grown at $24 / 17^{\circ} \mathrm{C}(\mathrm{MN}$, moderate temperature without fertilizer regimen) and the other at $37 / 28^{\circ} \mathrm{C}(\mathrm{HN}$, high temperature without fertilizer regimen). These growth conditions made it possible to determine the effects of fertilizer (MNvMF), high temperature $(\mathrm{MNvHN})$, and fertilizer plus high temperature (MNvHF) on gluten protein accumulation. It was also possible to evaluate the effects of high temperature on gluten protein accumulation in plants that received fertilizer (MFvHF) as well as the effects of fertilizer under high temperature conditions (HNvHF).

Fresh weight/grain was highest under the $24 / 17^{\circ} \mathrm{C}$ regimen with fertilizer (Figure 1A). Grain fresh weight was $79 \mathrm{mg}$ at $37 \mathrm{dpa}$ compared to $69 \mathrm{mg}$ without fertilizer. The $37 / 28^{\circ} \mathrm{C}$ regimens shortened the duration of grain fill from 37 to $21 \mathrm{dpa}$ and grain fresh weight was substantially less. Fresh weight/grain at $21 \mathrm{dpa}$ under the high temperature regimens was similar with or without fertilizer. Although mature grain produced under the high temperature regimens was much smaller, the germination rate was $100 \%$ (data not shown). Total gluten protein amount/grain, determined by the method

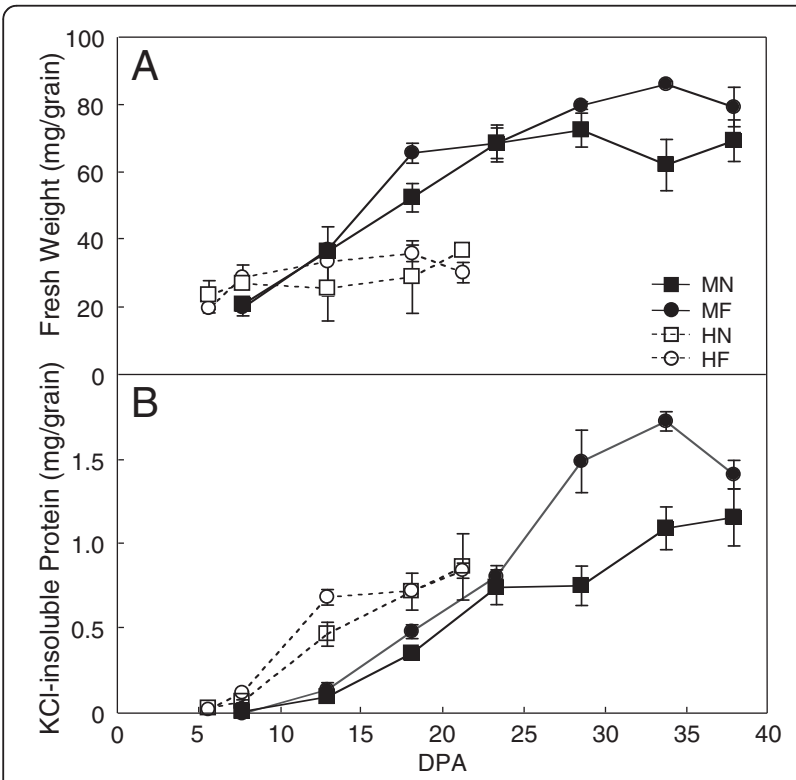

Figure 1 Effect of fertilizer and high temperature on fresh weight and gluten protein amounts in developing wheat grain. A. Fresh weight per grain. Grain from two heads per time point were analyzed. B. KCl-insoluble gluten protein per grain. Protein was extracted from endosperm collected from each of three heads per time point. MN, MF, HN, and HF are defined in Table 1. of Lowry et al. $[15,16]$ for the $\mathrm{KCl}$-insoluble protein fraction, was highest under the $24 / 17^{\circ} \mathrm{C}$ regimen with fertilizer (Figure 1B). At $37 \mathrm{dpa}$ under the $24 / 17^{\circ} \mathrm{C}$ regimens, gluten protein amount was somewhat higher with fertilizer than without. At $21 \mathrm{dpa}$ under the $37 / 28^{\circ} \mathrm{C}$ regimens, gluten protein amount was similar with or without fertilizer, but substantially less than under the $24 / 17^{\circ} \mathrm{C}$ regimens. The high temperature regimens also increased the percentage of gluten protein per grain. With fertilizer, gluten protein was $1.8 \%$ of grain fresh weight under the $24 / 17^{\circ} \mathrm{C}$ regimen compared to $2.6 \%$ under the $37 / 28^{\circ} \mathrm{C}$ regimen. Without fertilizer, gluten protein was $1.6 \%$ of fresh weight under the $24 / 17^{\circ} \mathrm{C}$ regimen compared to $2.2 \%$ under the $37 / 28^{\circ} \mathrm{C}$ regimen. The increase in the proportion of the gluten proteins per grain under the $37 / 28^{\circ} \mathrm{C}$ regimens is due to a decrease in starch levels under the high temperature regimens $[17,18]$.

\section{Principal component analysis reveals equivalent time points between the $24 / 17^{\circ} \mathrm{C}$ and $37 / 28^{\circ} \mathrm{C}$ time courses}

Proteins from endosperm collected at seven time points under the $24 / 17^{\circ} \mathrm{C}$ regimens and five time points under the $37 / 28^{\circ} \mathrm{C}$ regimens were separated by 2 -DE. Principal component analysis (PCA) of gluten protein gel patterns from triplicate gels for each time point was used to determine the relationships between the 24 time points comprising the four developmental time courses (Additional file 1 contains representative 2-D gels of all time points for the four treatments). Principal components 1 and 2 accounted for $78.3 \%$ of the variation in this analysis (Figure 2A). The three replicate gels for each time point clustered together, demonstrating excellent technical reproducibility of the 2-D gel patterns. PCA separated the gel patterns into four clusters that were aligned from the earliest to the latest time points along the $\mathrm{x}$-axis. Cluster a contained the $8 \mathrm{dpa}$ gel patterns for the $24 / 17^{\circ} \mathrm{C}$ regimens with or without fertilizer. Cluster b contained the $6 \mathrm{dpa}$ gel patterns for the $37 / 28^{\circ} \mathrm{C}$ regimen with fertilizer. Clusters $\mathrm{c}$ and $\mathrm{d}$ contained the gel patterns for the remaining time points. Within cluster $\mathrm{c}$, the gel patterns for the $24 / 17^{\circ} \mathrm{C}$ regimens with or without fertilizer at $13 \mathrm{dpa}$ were related to those for the $37 / 28^{\circ} \mathrm{C}$ regimens at $8 \mathrm{dpa}$ with fertilizer and 6 and 8 dpa without fertilizer. Within cluster $d$, the gel patterns for the $24 / 17^{\circ} \mathrm{C}$ regimen without fertilizer at $18,23,28$, 33 and $37 \mathrm{dpa}$ were located below the origin of the $y$-axis and the gel patterns for the $24 / 17^{\circ} \mathrm{C}$ regimen with fertilizer at $18,23,28,33$ and $37 \mathrm{dpa}$ and the $37 / 28^{\circ} \mathrm{C}$ regimens with and without fertilizer at 13,18 and $21 \mathrm{dpa}$ were located above the origin. This distribution suggests that the $24 / 17^{\circ} \mathrm{C}$ regimen without fertilizer was different from the other regimens and that it was a suitable treatment for determining gluten protein responses to fertilizer and high temperature. 

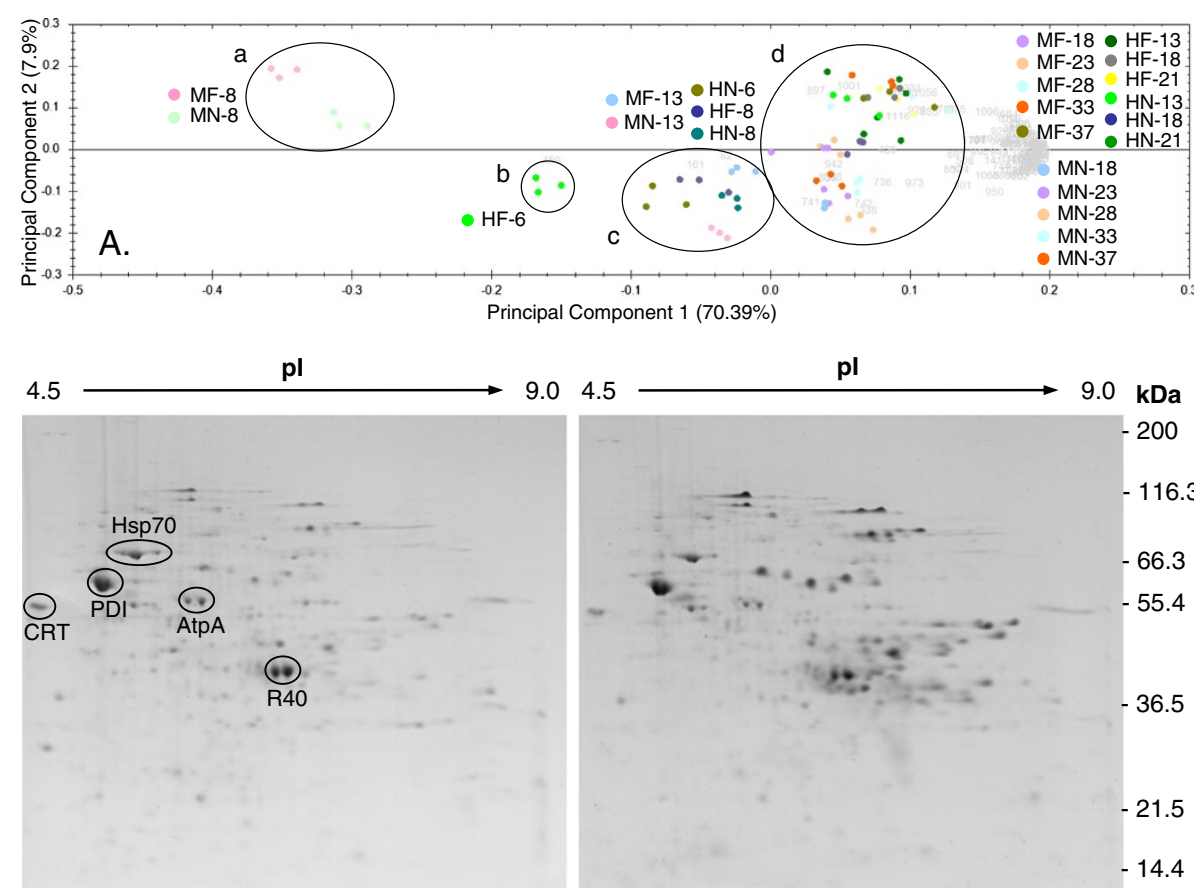

B. MF-8

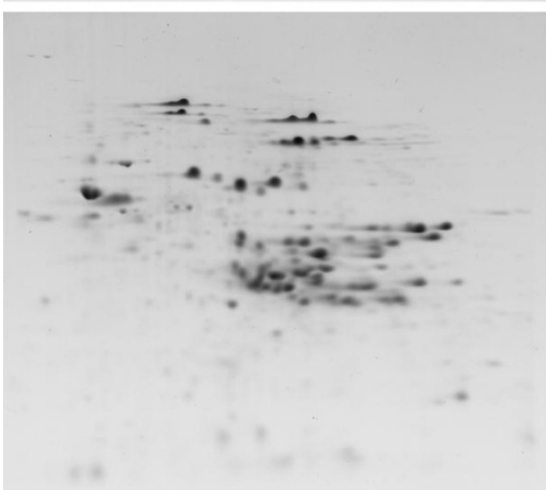

D. MF-13
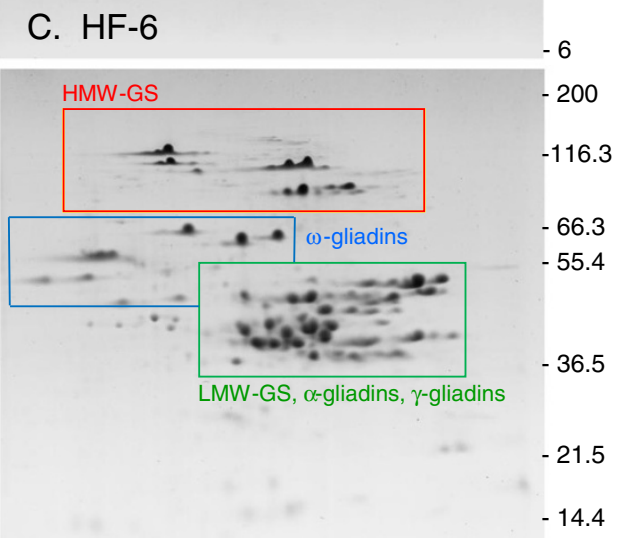

E. MF-37

Figure 2 Two-dimensional gel electrophoresis analysis of gluten proteins during wheat grain development. A. Principal component analysis. Each symbol corresponds to the gluten protein gel pattern at a single developmental time point. The analysis includes the three replicas for each time point. For cluster $d$, the keys to the color spots correspond to the location of gel patterns above or below the origin of the $y$-axis. B-E. Representative 2-D gels of samples from clusters a, b, c, and d: MF-8, HF-6, MF-13 and MF-37 dpa. MN, MF, HN, and HF are defined in Table 1. Boxes in E outline positions of the HMW-GS, the $\omega$-gliadins, and the LMW-GS plus a- and $\gamma$-gliadins. The proteome map and mass spectrometry data for identifications of individual proteins were reported previously [13]. Additional proteins identified in this study are indicated in panel B: AtpA, ATP synthase subunit alpha; CRT, calreticulin; Hsp70, 70 kD heat shock-induced protein; PDI, protein disulfide isomerase; R40, ABA- and stress-induced protein (Additional file 2 contains identification data).

Comparison of the 2-D gel patterns of proteins in the developing endosperm provided a partial explanation for the temporal distribution of the clusters generated by PCA (Figures $2 \mathrm{~B}-\mathrm{E}$ ). Under the $24 / 17^{\circ} \mathrm{C}$ regimen at 8 $\mathrm{dpa}$, the most abundant proteins were ATP synthase A (AtpA), calreticulin (CRT), $70 \mathrm{kD}$ heat shock protein (Hsp70), protein disulfide isomerase (PDI), and stress responsive protein R40 (R40) (Figure 2B). PDI and Hsp70 were identified previously $[13,19]$ and ATP synthase A (AtpA), calreticulin (CRT), and stress responsive protein R40 (R40) were identified in this study (Additional file 2 contains the MS/MS identification data). In keeping with the onset of gluten protein biosynthesis, CRT, Hsp70, and PDI, which reside in the ER, facilitate the folding and maturation of proteins. CRT also modulates calcium homeostasis and Hsp70 assists in transport of precursor 


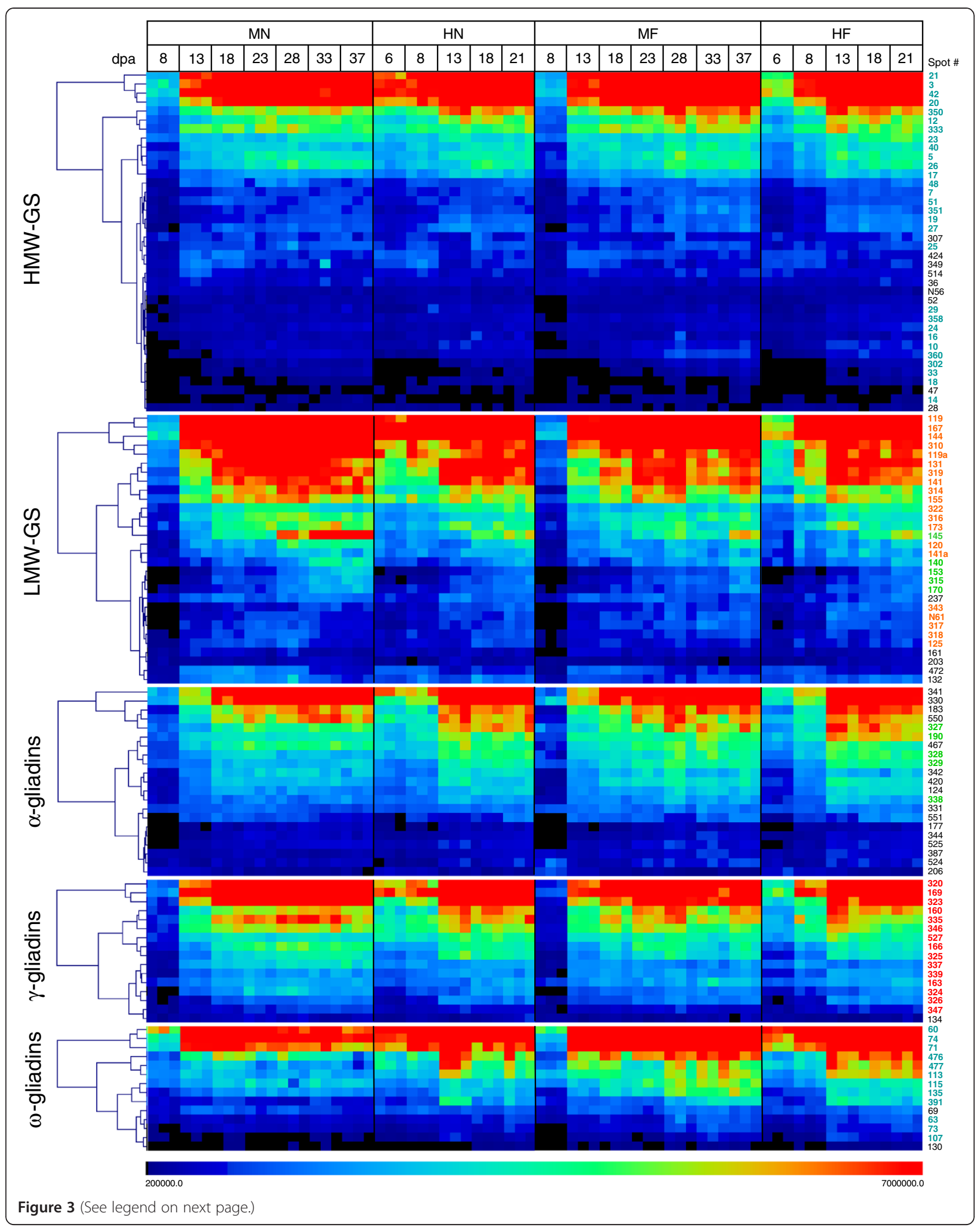


(See figure on previous page.)

Figure 3 Accumulation patterns of gluten proteins during wheat endosperm development. Accumulation profiles were analyzed by hierarchical cluster analysis and visualized using the TIGR Multiexperiment Viewer. Each square represents the normalized volume of a single 2-D gel spot. The color scale indicates relative protein amount. The dendrograms show the relationships between the profiles within each of the gluten protein classes. Additional file 3 contains the data set of normalized spot volumes. Spot numbers are color coded to match the subset of proteins selected by correlation analysis shown in Figure 4. HMW-GS N56 and the LMW-GS N61 were identified in developing endosperm and not detected in flour; Additional file 1, Figure MN-13 shows the map location and Additional file 2 contains the mass spectrometry data for these proteins. MN, MF, HN, and HF are defined in Table 1.

proteins into organelles and targets damaged proteins for degradation [20]. PDI regulates the formation, reduction, and isomerization of disulfide bonds associated with protein folding and AtpA is a key enzyme in bioenergetics. The specific role of the $\mathrm{R} 40$ proteins remains unclear. It has been proposed that these ABA- and osmotic stress-responsive proteins [21,22] have both protein- and carbohydrate-binding domains enabling them to cross-link proteins and glycoconjugates [23]. The non-gluten proteins appear to decrease throughout development, but this is due to a concomitant large increase in gluten protein accumulation that masks the presence of most non-gluten proteins. In an earlier study [19], a fraction in which gluten proteins were depleted was essential for analysis of non-gluten protein accumulation during Butte 86 grain development. Under the 24/ $17^{\circ} \mathrm{C}$ regimens, gluten proteins were present at very low levels at 8 dpa (Figure 2B), but comprised a major proportion of proteins from 13 to $37 \mathrm{dpa}$ (Figure 2D and $\mathrm{E}$, Additional file 1$)$. Under the $37 / 28^{\circ} \mathrm{C}$ regimens, gluten protein levels were more abundant at $6 \mathrm{dpa}$ (Figure $2 \mathrm{C}$ ) than at $8 \mathrm{dpa}$ under the $24 / 17^{\circ} \mathrm{C}$ regimens and comprised a major proportion of proteins from 8 to $21 \mathrm{dpa}$ (Additional file 1).

\section{High temperature and fertilizer alter individual gliadin and glutenin accumulation profiles during grain development}

Using protein identifications of 2-DE spots determined by MS/MS in Dupont et al. [13], protein profiles were grouped into the HMW-GS, LMW-GS, and the $\alpha_{-}^{-}, \gamma^{-}$, and $\omega$-gliadins. These were examined by hierarchical cluster analysis to provide a comprehensive image of the accumulation patterns of the gluten proteins during endosperm development under the four environmental regimens (Figure 3; original data in Additional file 3). The resulting display contains 8,208 data points: 24 experimental time points, 114 gluten protein spots, and spot volumes from triplicate 2-D gels. The spot volumes for the replicates clustered together at each time point, demonstrating excellent technical reproducibility of the 2-D gel patterns. The hierarchical cluster analysis ordered the accumulation profiles for each protein class by protein amount, which had a dynamic range of six orders of magnitude. Due to this wide dynamic range, a color scale of 200,000 to 7,000,000 was chosen to display the spot volume data. Depending on gluten protein class, $0.6-5.4 \%$ of the protein profiles with spot volumes less than 200,000 are off-scale and $7.7-16 \%$ with spot volumes greater $7,000,000$ are off-scale. The dendrograms in Figure 3 show the relationships between the protein profiles within each of the gluten protein classes. The identities of the gluten proteins corresponding to the profiles depicted in Figure 3 are located in Table 2 and are listed in Additional file 3 in the order determined by the hierarchical cluster analysis. Profiles of gluten protein accumulation under the $24 / 17^{\circ} \mathrm{C}$ regimens appeared similar with or without fertilizer. Most HMW-GS, LMW-GS, and $\alpha-, \gamma^{-}$, and $\omega$-gliadins increased rapidly between 8 and $13 \mathrm{dpa}$ and then increased gradually from 13 to $37 \mathrm{dpa}$. The $37 / 28^{\circ} \mathrm{C}$ regimens compressed the developmental profiles; proteins increased rapidly between 6 and $8 \mathrm{dpa}$ and attained maximal levels from 13 to $21 \mathrm{dpa}$.

Because individual profiles were difficult to distinguish in Figure 3, correlation analysis was used to investigate accumulation profiles in more detail. Protein profiles were grouped into HMW-GS, LMW-GS, and the $\alpha-, \gamma^{-}$, and $\omega-$ gliadins, spot volumes log normalized, and accumulation patterns analyzed (Figure 4). The profiles include the three replicate spot volumes for each time point and are color coded to match the spot numbers in Figure 3. This analysis showed, with the exception of a few outliers, that the profiles for the HMW-GS and the $\gamma$ - and $\omega$-gliadins formed single clusters under each of the environmental treatments while the LMW-GS formed two clusters. The $\alpha$-gliadins exhibited greater variability and only five of the 21 profiles clustered together.

Under the $24 / 17^{\circ} \mathrm{C}$ regimen without fertilizer, the gluten proteins exhibited four developmental profiles (Figure 4, $\mathrm{MN})$. The HMW-GS and $\alpha$-gliadins reached maximum levels at $18 \mathrm{dpa}$ and remained at these levels until $37 \mathrm{dpa}$. The $\omega$-gliadins attained maximum levels at 13-18 dpa and declined slightly by $37 \mathrm{dpa}$. The majority of LMW-GS (Figure 4, LMW-GS $\mathrm{A}_{\mathrm{A}}$ ) had profiles similar to the $\gamma$ gliadins and attained maximum levels at $28 \mathrm{dpa}$ and declined slightly by $37 \mathrm{dpa}$. A small group of LMW-GS (spots 140, 145, 153, 170, 315) increased gradually throughout development and attained maximum levels at 
Table 2 Effect of temperature and fertilizer on accumulation of individual gluten proteins in flour

\begin{tabular}{|c|c|c|c|c|c|c|c|c|c|c|c|c|c|c|c|}
\hline \multirow[t]{3}{*}{ Predominant protein ${ }^{1}$} & \multirow[t]{3}{*}{ \# Spots } & \multirow[t]{3}{*}{ Spot numbers ${ }^{5}$} & \multicolumn{8}{|c|}{ Spot volume $\times 10^{-5(6)}$} & \multicolumn{5}{|c|}{$\%$ Change $^{11}$} \\
\hline & & & \multicolumn{2}{|c|}{$\mathrm{MN}^{7}$} & \multicolumn{2}{|c|}{$\mathrm{MF}^{8}$} & \multicolumn{2}{|c|}{$\mathrm{HN}^{9}$} & \multicolumn{2}{|c|}{$\mathrm{HF}^{10}$} & \multirow[t]{2}{*}{ MNvMF } & \multirow[t]{2}{*}{ HNvHF } & \multirow[t]{2}{*}{ MNvHN } & \multirow[t]{2}{*}{ MNvHF } & \multirow[t]{2}{*}{ MFvHF } \\
\hline & & & Ave & SD & Ave & SD & Ave & SD & Ave & SD & & & & & \\
\hline$A \times 2+$ & 8 & $12,16,17,18,19,23,24,28$ & 66.8 & 2.8 & 91.3 & 2.7 & 91.0 & 1.2 & 94.5 & 6.3 & 36.7 & 3.8 & 36.3 & 41.6 & 3.5 \\
\hline $\mathrm{B} \times 7+$ & 8 & $20,21,25,26,27,29,33,302$ & 136.3 & 6.7 & 170.6 & 2.7 & 164.8 & 2.0 & 161.6 & 8.1 & 25.2 & -2.0 & 21.0 & 18.6 & -5.3 \\
\hline Dx5t & 8 & $3,5,7,10,14,36,307,538$ & 96.7 & 0.9 & 121.6 & 5.3 & 128.9 & 0.2 & 130.1 & 5.9 & 25.7 & 0.9 & 33.4 & 34.6 & 7.0 \\
\hline By9t & 8 & $\begin{array}{c}40,47,52,349,350,351,358 \\
360\end{array}$ & 50.7 & 1.8 & 75.6 & 3.5 & 77.8 & 2.4 & 77.0 & 5.6 & 49.2 & -1.1 & 53.6 & 52.0 & 1.8 \\
\hline Dy10† & 6 & $42,48,51,333,424,514$ & 88.3 & 6.0 & 104.7 & 8.4 & 105.2 & 6.0 & 98.1 & 10.5 & 18.6 & -6.7 & 19.1 & 11.1 & -6.3 \\
\hline \multicolumn{16}{|l|}{ LMW-GS ${ }^{2}$} \\
\hline Bu-1 (m-type) & 2 & $167,170 \neq$ & 94.9 & 4.6 & 99.2 & 6.2 & 94.5 & 4.2 & 98.1 & 7.1 & 4.5 & 3.8 & -0.5 & 3.3 & -1.1 \\
\hline Bu-3† (s-type) & 9 & $\begin{array}{c}119,119 a, 120,131,132,161 \\
237,310,316\end{array}$ & 282.5 & 7.5 & 258.1 & 7.5 & 247.1 & 13.8 & 237.3 & 4.8 & -8.6 & -3.9 & -12.5 & -16.0 & -8.1 \\
\hline Bu-4 (i-type) & 3 & $140 \neq, 141,141 a$ & 76.8 & 3.1 & 82.9 & 0.5 & 82.2 & 7.1 & 83.0 & 2.8 & 8.0 & 0.9 & 7.1 & 8.0 & 0.0 \\
\hline Bu-6† (m-type) & 1 & 173 & 35.1 & 4.1 & 27.0 & 2.8 & 30.5 & 6.0 & 26.9 & 2.4 & -23.1 & -11.6 & -13.1 & -23.2 & -0.1 \\
\hline Bu-7† (m-type) & 3 & $144,145 \neq, 472$ & 102.6 & 4.6 & 88.3 & 5.5 & 93.5 & 8.9 & 87.7 & 3.2 & -14.0 & -6.1 & -8.9 & -14.5 & -0.7 \\
\hline Bu-8 (m-type) & 1 & 343 & 3.4 & 0.3 & 2.8 & 0.1 & 3.1 & 0.8 & 3.3 & 0.7 & -18.7 & 6.6 & -10.1 & -4.2 & 17.9 \\
\hline Bu-11 (m-type) & 2 & $203,315 \neq$ & 17.7 & 1.1 & 12.2 & 1.5 & 11.0 & 1.3 & 12.3 & 1.3 & -31.4 & 11.6 & -37.9 & -30.7 & 1.1 \\
\hline Bu-18 (m-type) & 2 & $153 \neq, 155$ & 40.1 & 4.3 & 35.4 & 3.3 & 37.1 & 6.9 & 33.6 & 1.9 & -11.7 & -9.6 & -7.4 & -16.2 & -5.1 \\
\hline Bu-2/13 (s-type) & 4 & $314,317,318,322$ & 92.8 & 7.7 & 101.1 & 3.3 & 98.2 & 3.2 & 90.6 & 4.9 & 9.0 & -7.7 & 5.8 & -2.3 & -10.4 \\
\hline GenBank: AAB48469 (i-type) & 1 & 125 & 6.5 & 0.2 & 6.1 & 0.4 & 7.4 & 0.2 & 7.7 & 1.0 & -6.3 & 3.9 & 14.5 & 18.9 & 26.8 \\
\hline TC11-277270 (m-type) & 1 & 319 & 31.6 & 3.6 & 29.8 & 2.7 & 35.6 & 4.2 & 32.5 & 1.2 & -5.7 & -8.7 & 12.5 & 2.8 & 9.0 \\
\hline \multicolumn{16}{|l|}{ a-Gliadins } \\
\hline Bu-1† & 1 & 342 & 11.5 & 0.6 & 14.7 & 1.8 & 12.3 & 10.6 & 11.2 & 1.0 & 27.9 & -9.4 & 7.6 & -2.5 & -23.7 \\
\hline $\mathrm{Bu}-2^{3}$ & 2 & 330,338 & 86.8 & 1.1 & 97.8 & 2.9 & 87.0 & 1.5 & 90.4 & 4.0 & 12.6 & 3.9 & 0.2 & 4.1 & -7.5 \\
\hline Bu-3† & 1 & 468 & 40.4 & 1.5 & 46.7 & 5.6 & 42.9 & 0.5 & 43.5 & 3.0 & 15.6 & 1.5 & 6.0 & 7.6 & -6.9 \\
\hline Bu-4t & 1 & 467 & 53.6 & 3.1 & 62.0 & 2.5 & 59.9 & 1.3 & 58.4 & 2.7 & 15.7 & -2.5 & 11.7 & 8.9 & -5.9 \\
\hline Bu-5 & 2 & 183,344 & 38.6 & 0.3 & 46.9 & 2.0 & 48.3 & 3.0 & 46.5 & 5.2 & 21.7 & -3.7 & 25.2 & 20.5 & -1.0 \\
\hline Bu-10 & 1 & 550 & 27.9 & 1.4 & 33.8 & 1.3 & 31.5 & 8.0 & 32.6 & 3.0 & 21.5 & 3.6 & 13.0 & 17.1 & -3.6 \\
\hline Bu-11 & 1 & 327 & 47.4 & 4.0 & 69.6 & 4.4 & 67.0 & 7.6 & 69.0 & 4.7 & 46.7 & 3.0 & 41.3 & 45.5 & -0.8 \\
\hline Bu- $12 t^{4}$ & 5 & $328,329,387,524,525$ & 78.6 & 2.3 & 118.1 & 1.9 & 106.7 & 10.2 & 114.7 & 3.9 & 50.2 & 7.5 & 35.7 & 45.9 & -2.9 \\
\hline Bu-14† & 4 & 190, 206, 331, 551 & 33.3 & 0.5 & 42.5 & 2.4 & 45.2 & 1.6 & 48.3 & 6.8 & 27.5 & 7.0 & 35.7 & 45.2 & 13.8 \\
\hline$B u-23^{4}$ & 1 & 341 & 92.0 & 3.3 & 97.1 & 2.4 & 95.0 & 5.2 & 91.6 & 3.9 & 5.5 & -3.6 & 3.2 & -0.5 & -5.7 \\
\hline Bu-27 & 1 & 420 & 14.7 & 1.4 & 17.8 & 2.1 & 17.5 & 1.5 & 16.3 & 0.9 & 21.2 & -7.2 & 19.1 & 10.5 & -8.9 \\
\hline
\end{tabular}


Table 2 Effect of temperature and fertilizer on accumulation of individual gluten proteins in flour (Continued)

\begin{tabular}{|c|c|c|c|c|c|c|c|c|c|c|c|c|c|c|c|}
\hline Bu (GenBank:BQ806209) & 1 & 177 & 7.0 & 0.5 & 5.9 & 1.3 & 5.1 & 0.7 & 4.5 & 0.5 & -16.0 & -12.2 & -27.1 & -36.0 & -23.7 \\
\hline Bu (GenBank:BQ807130)† & 1 & 124 & 11.4 & 1.3 & 15.3 & 2.6 & 16.1 & 1.7 & 15.3 & 0.4 & 33.9 & -5 & 41.1 & 34.1 & 0.1 \\
\hline \multicolumn{16}{|l|}{ Y-Gliadins } \\
\hline Bu-1† & 1 & 326 & 4.9 & 0.4 & 3.5 & 0.7 & 3.9 & 1.7 & 3.1 & 0.6 & -28.1 & -19.8 & -20.5 & -36.2 & -11.3 \\
\hline Bu-2 & 1 & 160 & 72.4 & 2.2 & 80.7 & 3.0 & 84.4 & 3.5 & 87.9 & 3.5 & 11.4 & 4.2 & 16.5 & 21.4 & 9.0 \\
\hline $\mathrm{Bu}-4^{3}$ & 3 & $166,169,337$ & 92.4 & 5.2 & 85.6 & 8.0 & 92.7 & 8.9 & 84.8 & 0.4 & -7.4 & -8.5 & 0.2 & -8.3 & -0.9 \\
\hline Bu-5 & 4 & $134,320,323,324$ & 142.9 & 5.1 & 132.7 & 6.6 & 132.9 & 9.8 & 127.9 & 6.9 & -7.1 & -3.8 & -7.0 & -10.5 & -3.6 \\
\hline Bu-6 & 3 & $335,346,347$ & 67.4 & 8.7 & 72.2 & 2.4 & 78.3 & 6.1 & 76.2 & 4.0 & 7.1 & -2.7 & 16.3 & 13.1 & 5.5 \\
\hline Bu-7 & 1 & 339 & 10.6 & 1.4 & 9.6 & 1.1 & 9.5 & 0.8 & 7.8 & 1.2 & -9.7 & -17.6 & -10.6 & -26.4 & -18.5 \\
\hline Bu-11 & 2 & 163,527 & 32.3 & 1.1 & 32.2 & 1.6 & 36.5 & 3.3 & 37.0 & 0.9 & -0.2 & 1.4 & 13.1 & 14.7 & 15.0 \\
\hline $\mathrm{Bu}-1$ or $\mathrm{Bu}-8^{3}$ & 1 & 325 & 31.3 & 1.5 & 34.6 & 1.8 & 32.9 & 5.0 & 32.0 & 3.8 & 10.5 & -2.8 & 5.4 & 2.5 & -7.3 \\
\hline \multicolumn{16}{|l|}{$\omega$-Gliadins } \\
\hline Gli-B3 type $(\omega-5) \dagger$ & 6 & $60,63,69,71,73,74$ & 110.9 & 2.8 & 230.3 & 2.6 & 180.9 & 20.9 & 186.1 & 20.9 & 107.6 & 2.9 & 63.1 & 67.8 & -19.2 \\
\hline Gli-D3 type $(\omega-1,2) \dagger$ & 2 & 476,477 & 60.1 & 3.4 & 109.4 & 5.3 & 108.2 & 15.5 & 106.7 & 15.5 & 82.0 & -1.4 & 80.1 & 77.5 & -2.4 \\
\hline Bu-D5 $(\omega-1,2) \dagger$ & 2 & 135,391 & 25.5 & 2.5 & 50.8 & 4.4 & 45.7 & 10.1 & 49.5 & 10.1 & 99.2 & 8.2 & 79.5 & 94.3 & -2.5 \\
\hline $\begin{array}{l}\text { Cys type TC-262770 } \\
(\omega-1,2) \dagger^{3}\end{array}$ & 4 & $107,113,115,116$ & 41.2 & 3.7 & 64.2 & 5.1 & 63.6 & 9.5 & 66.6 & 9.5 & 56.0 & 4.6 & 54.6 & 61.7 & 3.6 \\
\hline secalin-like & 1 & 130 & 3.5 & 0.5 & 3.6 & 0.5 & 3.1 & 0.4 & 3.5 & 0.4 & 2.7 & 13.0 & -10.1 & 1.6 & -1.0 \\
\hline
\end{tabular}

Proteins were identified in Dupont et al. [13]

${ }_{2}^{2}$ LMW-GS are classified as $\mathrm{m}$-, s- or i-type based on their $\mathrm{N}$-terminal amino acid sequence.

${ }^{3}$ Denotes gliadins containing odd numbers of cysteines.

${ }_{5}^{4}$ Denotes a-gliadins that do not contain Glia-a, Glia-a2, Glia-a-9 or Glia-a-20 celiac disease epitopes.

${ }^{5}$ Spots containing same gene sequences.

${ }_{7}^{6}$ Ave and SD refer to average and standard deviation of normalized volumes from all spots with the same identification. Additional file 4 contains the data set of normalized spot volumes.

${ }^{7} \mathrm{MN}, 24 / 17^{\circ} \mathrm{C}$ minus fertilizer.

${ }^{8} \mathrm{MF}, 24 / 17^{\circ} \mathrm{C}$ plus fertilizer.

${ }^{9} \mathrm{HN}, 37 / 28^{\circ} \mathrm{C}$ minus fertilizer.

${ }^{10} \mathrm{HF}, 37 / 28^{\circ} \mathrm{C}$ plus fertilizer.

${ }^{11}$ Increases of $20 \%$ or more are indicated in bold type and decreases of $20 \%$ or more are indicated in bold italics type.

† Proteins that responded significantly to fertilizer in Altenbach et al. [14].

₹ Spot numbers of proteins comprising LMW-GS ${ }_{B}$, a group of LMW-GS sharing a unique developmental profile. 


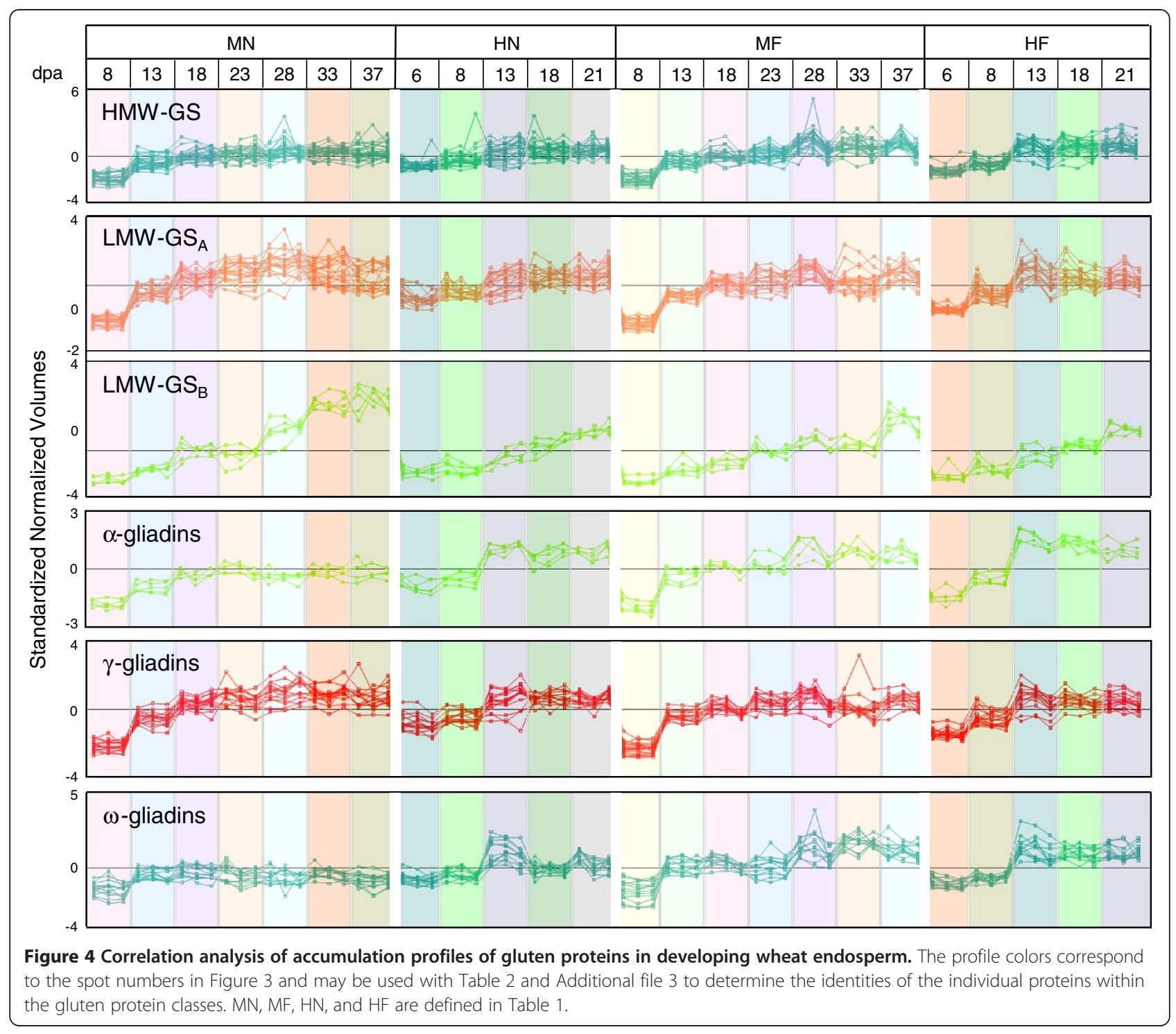

$37 \mathrm{dpa}$ (Figure 4, LMW-GS ${ }_{\mathrm{B}}$, indicated by $\neq$ in the Spot Numbers column in Table 2). These spots were identified as the m-type LMW-GS Bu-1, Bu-7, Bu-11 and Bu-18 and the i-type LMW-GS Bu-4 [13]. Under the $24 / 17^{\circ} \mathrm{C}$ regimen with fertilizer, the gluten proteins exhibited only two developmental profiles (Figure 4, MF). The HMW-GS, LMW-GS $_{\mathrm{A}}$, and the $\alpha-, \gamma^{-}$, and $\omega$-gliadins peaked at 28 and the LMW-GS $S_{\mathrm{B}}$ were maximal at $37 \mathrm{dpa}$. Compared to the $24 / 17^{\circ} \mathrm{C}$ regimen without fertilizer, the HMW-GS, $\alpha-$ gliadins, and $\omega$-gliadins were higher from $28-37 \mathrm{dpa}$, the

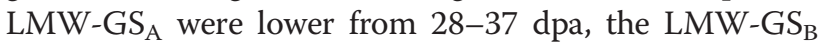
were lower from 18-37 dpa, and the $\gamma$-gliadins were somewhat lower at $33 \mathrm{dpa}$ (Figure 4, compare MN and $\mathrm{MF})$. At $37 \mathrm{dpa}$, the most notable changes in gluten protein levels were increases in the $\alpha$ - and $\omega$-gliadins and decreases in the LMW-GS $S_{B}$.
Under the $37 / 28^{\circ} \mathrm{C}$ regimens, the gluten proteins exhibited three developmental profiles without and with post-anthesis fertilizer (Figure 4, HN and HF). The HMW-GS and LMW-GS $\mathrm{A}_{\mathrm{A}}$ attained maximum levels at $13 \mathrm{dpa}$ and remained at these levels until $21 \mathrm{dpa}$. The $\alpha-, \gamma^{-}$, and $\omega$-gliadins also peaked at $13 \mathrm{dpa}$, but declined slightly by $21 \mathrm{dpa}$. The LMW-GS $\mathrm{B}_{\mathrm{B}}$ increased gradually throughout development and attained maximum levels at $21 \mathrm{dpa}$. The most notable changes in gluten protein levels at $21 \mathrm{dpa}$ under the two high temperature regimens were increases in the $\omega$-gliadins.

\section{High temperature and fertilizer alter levels of specific} gliadins and glutenins in flour

Since flour quality depends on gluten protein composition, the effect of fertilizer and high temperature on 
gluten protein levels was examined in flour milled from mature grain harvested from plants used for the developmental studies (original data in Additional file 4). Because the same protein sequences were often associated with multiple 2-D spots, the volumes of spots containing proteins with the same identifications were summed for this analysis as was done by Altenbach et al. [14]. This resulted in 42 different gluten proteins (Table 2). The percent change in volume relative to the $24 / 17^{\circ} \mathrm{C}$ regimen without fertilizer was calculated to determine specific gluten protein responses to fertilizer, high temperature, and high temperature plus fertilizer. In a previous study, 19 gluten proteins showed statistically significant changes of $20 \%$ or more in response to fertilizer under a $24 / 17^{\circ} \mathrm{C}$ regimen (Table 2 , indicated by † in the Predominant Protein column) [14]. In this study, it is notable that 14 proteins responded not only to fertilizer (MNvMF), but also to high temperature $(\mathrm{MNvHN})$ and high temperature plus fertilizer (MNvHF). These included three HMW-GS (Ax2*, Dx5, By9), one m-type LMW-GS (Bu-11), five $\alpha$-gliadins (Bu-5, $\mathrm{Bu}-11, \mathrm{Bu}-12, \mathrm{Bu}-14, \mathrm{Bu}-\mathrm{BQ} 807130)$, one $\gamma$-gliadin (Bu-1) and one $\omega-5$ gliadin and three $\omega-1,2$ gliadins.

The effects of fertilizer and high temperature were not additive. In fact, only three low abundance proteins differed $20 \%$ or more in amount when plants that received fertilizer were subjected to high temperature (MFvHF); an i-type LMW-GS (GenBank: AAB48469) increased and two $\alpha$-gliadins (Bu-1, Bu-BQ806209) decreased. In addition, protein abundance changed little when plants subjected to high temperature received fertilizer (HNvHF). A comparison of percent change of the gluten protein groups (Figure 5) in response to fertilizer, temperature, and high temperature plus fertilizer showed that the HMW-GS, $\alpha$-gliadins, and $\omega$-gliadins increased, the LMW-GS decreased, and the $\gamma$-gliadins showed little change in response to fertilizer, high temperature or fertilizer plus high temperature. The increases were greatest for the $\omega$-gliadins and much less for the HMW-GS and $\alpha$-gliadins. After accounting for gliadins containing extra cysteines (indicated in Table 2), ratios of gliadins to glutenins increased from 0.71 for the $\mathrm{MN}$ treatment to $0.86,0.81$ and 0.84 for the MF, HN and HF treatments, respectively. Ratios of HMW-GS to LMW-GS also increased from 0.44 for the MN treatment to $0.57,0.58$ and 0.59 for the MF, HN and HF treatments, respectively.

\section{Discussion}

\section{Effect of fertilizer and high temperature on developmental profiles of gluten proteins}

Quantitative 2-DE was used to determine the effects of post-anthesis fertilizer and high temperature on the accumulation of individual gliadins and glutenins in the developing endosperm and in flour milled from the mature grain. To distinguish responses to temperature from those of fertilizer, plants were grown under $24 / 17^{\circ} \mathrm{C}$ and $37 / 28^{\circ} \mathrm{C}$ regimens without and with post-anthesis fertilizer. 2-DE spots identified as HMW-GS, $\omega$-gliadins or $\gamma$-gliadins generally showed expression profiles characteristic of each protein group while spots identified as $\alpha$-gliadins showed a variety of expression profiles. Individual LMW-GS spots exhibited two distinctly different developmental profiles. One group (LMW-GS ${ }_{\mathrm{A}}$ ) had expression profiles similar to the $\gamma$-gliadins and another group $\left(\mathrm{LMW}-\mathrm{GS}_{\mathrm{B}}\right.$ ) increased gradually throughout development. Of the five proteins comprising $L M W-G S_{B}$, four were identified by MS/MS as m-type LMW-GS (Bu-1, Bu-7, Bu-11, Bu-18) and one as an i-type LMWGS (Bu-4) (Table 2). These proteins had the same MS/ MS identities as other proteins in the LMW- $\mathrm{GS}_{\mathrm{A}}$ group, but had different pIs and $\mathrm{M}_{\mathrm{r}} \mathrm{s}$. Although MS/MS sequence coverage for these LMW-GS was quite high, generally about $50 \%$, differences in the expression profiles suggest that very similar proteins in the LMW$\mathrm{GS}_{\mathrm{A}}$ and $\mathrm{LMW}-\mathrm{GS}_{\mathrm{B}}$ groups are encoded by different genes. Juhász et al. [24] recently found two expression profiles for LMW-GS genes. However, they reported that s-type and i-type LMW-GS had expression profiles similar to the LMW-GS $\mathrm{B}_{\mathrm{B}}$ in the present study. Liu et al. [25] also reported multiple expression profiles for LMW-GS genes in a proteomic analysis of three Chinese wheat cultivars.

The developmental profiles demonstrate that gluten protein accumulation is a complex process that is subject to spatial and temporal regulation as well as environmental signaling. Individual proteins within each gluten protein class accumulated to different levels, suggesting that the corresponding genes had different basal levels of expression. Ultimately, the proportions of $\omega$-gliadins and HMW-GS and a few $\alpha$-gliadins and LMW-GS changed in flour in response to both postanthesis fertilizer and high temperature while those of most $\alpha$ - and $\gamma$-gliadins and LMW-GS were unchanged. The data suggest that there are differences in the promoter sequences of the gluten protein genes, both between and within the major gene families. Promoter elements responsible for tissue specificity of the gluten proteins are the endosperm box, which is comprised of the prolamin box and a GCN4-like motif (GLM), and the AACA motif $[26,27]$. GLM, also known as the N motif, is thought to play a role in the response of the gluten protein genes to nitrogen [28,29]. Recently, Juhász et al. [24] compared regulatory elements in the $5^{\prime}$ non-coding regions of LMW-GS genes available in public databases and developed a model for their transcriptional regulation based on an in silico analysis of expression profiles. Clearly, it will be important to 


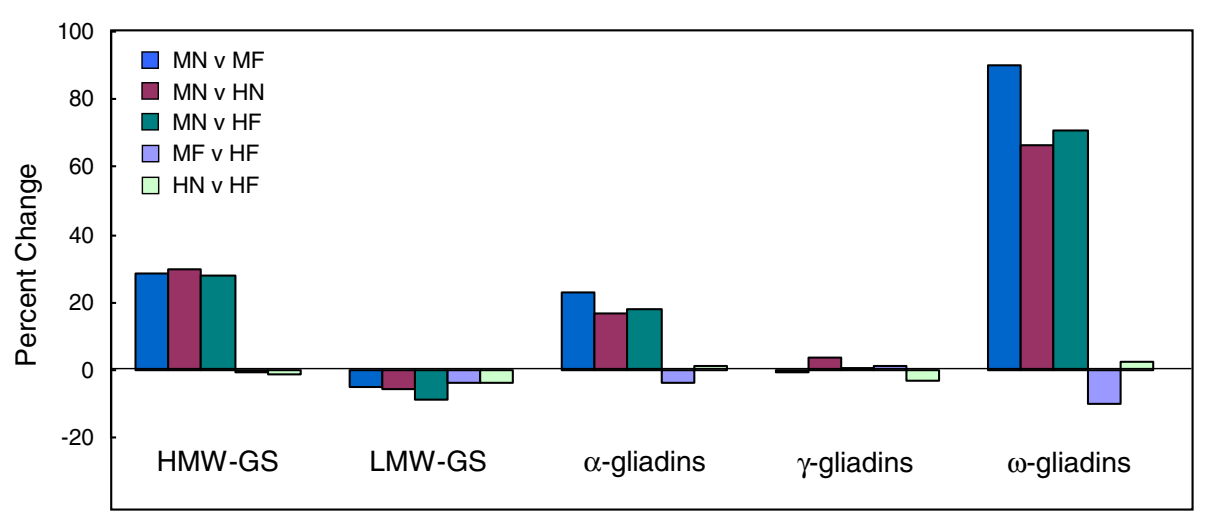

Figure 5 Effect of temperature and fertilizer on proportion of gluten protein classes in flour. Comparisons of percent change in relative volumes of gluten protein classes were made for MNvMF, MNvHN, MNvHF, MFvHF and HNvHF. Additional file 4 contains the data set of normalized spot volumes. MN, MF, HN, and HF are defined in Table 1.

confirm this model using experimental data and extend the model to include other classes of gluten protein genes. Comparisons of promoter regions from genes encoding gluten proteins characterized in this study should prove valuable for this type of analysis.

\section{Effect of fertilizer and high temperature on gluten protein composition in flour}

Dupont et al. [6] used RP-HPLC to quantify the effects of fertilizer and high temperature on the accumulation of Butte 86 flour proteins and reported changes in the levels of $\omega$-gliadins and HMW-GS. However, changes in specific LMW-GS, $\alpha$ - and $\gamma$-gliadins were difficult to detect because of the complexity of these groups of proteins. In this study, 2-DE analysis revealed a number of changes in distinct gluten proteins within these classes in response to fertilizer and temperature. Of the 42 uniquely identified gluten proteins, 16 increased with fertilizer under moderate temperatures (four HMW-GS, eight $\alpha$-gliadins, and four $\omega$-gliadins) and three decreased (two LMW-GS and one $\gamma$-gliadin). The response to the $37 / 28^{\circ} \mathrm{C}$ regimen without fertilizer (MNvHN) was comparable to that of $24 / 17^{\circ} \mathrm{C}$ regimen with fertilizer (MNvMF); thirteen of the same proteins increased (four HMW-GS, five $\alpha$-gliadins, and four $\omega$-gliadins) and two of the same proteins decreased (one LMW-GS and one $\gamma$-gliadin). Most of these proteins also responded to high temperature plus fertilizer (MNvHF). It is notable that the effects of fertilizer and high temperature were not additive and that very few significant changes were observed when plants receiving fertilizer were subjected to high temperature (MFvHF). Likewise, the application of fertilizer under a high temperature regimen had little effect on gluten protein accumulation (HNvHF). As noted previously $[5,14,30,31]$, the response to high temperature and fertilizer is related to the proportion of the S-containing amino acids in the different gluten protein classes.
Generally, the proportions of low S-proteins ( $\omega$-gliadins) and low to medium S-proteins (HMW-GS and $\alpha$-gliadins) increased and those of the high S-proteins (LMW-GS and $\gamma$-gliadins) remained the same or decreased.

In agreement with previous studies [6,14,32], the ratios of gliadins to glutenins increased in response to fertilizer and high temperature. The higher ratios reflect increases in the proportions of $\omega$-gliadins and certain $\alpha$-gliadins. The ratios of the HMW-GS to LMW-GS also increased in response to both fertilizer and high temperature, largely due to increases in HMW-GS and decreases in certain LMW-GS. Of the gliadins containing an odd number of cysteines and likely to function as LMW-GS, only the cys-type $\omega$-gliadins showed responses to fertilizer or high temperature. Others have reported that the ratio of the HMW-GS to LMW-GS in a glutenin polymer fraction of SDS unextractable protein is significantly correlated with dough strength [33-37].

Because individual proteins in this analysis were associated with specific gene sequences, changes in the immunogenic potential of the flour that result from the growth conditions of the plant can now be assessed. It is notable that the Gli-B3 $\omega$-gliadins (also referred to as $\omega-5$ gliadins) are associated with the food allergy wheatdependent exercise-induced anaphylaxis. These proteins increased significantly in response to both fertilizer and temperature. Among the gluten proteins, the $\alpha$-gliadins are considered most immunogenic in celiac disease. Several of the $\alpha$-gliadins that increased in response to both fertilizer and temperature contain epitopes important in celiac disease (Bu-5, Bu-11, Bu-14) while others do not contain these sequences (Bu-12) (Table 2) $[13,38]$. It is interesting that proteins that do not contain celiac epitopes comprised $31-32 \%$ of the total $\alpha$-gliadins under all treatments, suggesting that neither fertilizer nor temperature influenced the immunogenic potential of the flour with respect to celiac disease. The accu- 
mulation of other immunogenic proteins were not assessed in this study. However, Altenbach et al. [14] analyzed a fraction of total SDS-extractable protein and reported changes in the proportions of other proteins with fertilizer that are likely food allergens. These included increases in serpins and decreases in lipid transfer protein (LTP), chitinase, the $\alpha$-amylase/trypsin inhibitor CM3 and globulin-2. Hurkman et al. [19] analyzed an albumin/globulin fraction and reported that the same proteins had opposite responses to high temperature when plants were supplied with fertilizer. They observed increases in LTP, chitinase and globulin-2 and decreases in the proportions of several serpins.

\section{Source-sink activities and gluten protein responses to fertilizer and high temperature}

The question arises as to why post-anthesis high temperature and the post-anthesis addition of fertilizer alter gluten protein composition in the same manner. The similarity in responses of the gliadins and glutenins to high temperature and fertilizer might be explained by sourcesink activities in the wheat plant [39-45]. All plants were grown with fertilizer and adequate water under moderate temperatures until anthesis so the amount of nitrogen and carbon reserves that could be mobilized to the developing grain for the synthesis of protein and starch were comparable at the beginning of the treatments. The addition of post-anthesis fertilizer enhances the remobilization of reserves during grain fill and the rate of protein accumulation in the grain, resulting in increases in flour protein percentage and specific changes in gliadin and glutenin composition in flour $[5,6,14]$. On the other hand, high temperature conditions elicit premature leaf senescence and shorten the period of grain fill [39]. Because remobilization of nitrogen reserves to the developing grain occurs over a significantly shorter period of time, the temperature treatment may essentially mimic high nitrogen conditions, resulting in changes in the same complement of gluten proteins. The lack of response to fertilizer under high temperature conditions suggests that the plants are unable to utilize fertilizer under the temperatures used in this study. This would also explain why post-anthesis fertilizer and temperature do not elicit an additive response.

\section{Conclusions}

This study provides insight into the manner in which specific growth conditions during wheat grain development influence the accumulation of the individual gluten proteins that determine flour quality. While many gluten proteins respond to fertilizer and high temperature, most of the changes are small in magnitude and surprisingly similar between the two treatments. It is notable that both fertilizer and high temperature increase the proportions of most HMW-GS and $\omega$-gliadins and some of the same $\alpha$ gliadins while decreasing the proportions of several LMW-GS and a minor $\gamma$-gliadin. A critical question is how the observed changes in gluten protein composition influence flour quality. Many different proteins contribute to flour quality. While the roles of HMW-GS have received considerable attention, the functions of individual LMW-GS and gliadins in flour quality remain poorly defined. The identification of genes within these classes that respond to fertilizer or temperature now makes it possible to utilize transgenic approaches to determine the importance of specific proteins in flour quality and in the response of the grain to the environment. For example, RNA interference was used recently to create transgenic Butte 86 plants in which genes encoding the $\omega-5$ gliadins were silenced [46]. Since these proteins show some of the largest responses to fertilizer and temperature, analyses of transgenic lines should elucidate how the proteome responds to fertilizer and high temperature in their absence and reveal the contribution of the $\omega-5$ gliadins to flour quality.

\section{Methods}

\section{Plant material}

Triticum aestivum L. cv. Butte 86 was grown in climatecontrolled greenhouses as described previously [14,47]. Seven seeds were sown per pot $(25 \mathrm{~cm}$ diameter by $24 \mathrm{~cm}$ high). The pots contained Sunshine Mix Number 1 (SunGro Horticulture, Inc., Bellevue, WA, USA), a planting mix that contains $70-80 \%$ Sphagnum peat moss plus perlite, dolomitic limestone, gypsum, and wetting agent. Prior to anthesis, plants were grown at a maximum daytime temperature of $24^{\circ} \mathrm{C}$ and a minimum nighttime temperature of $17^{\circ} \mathrm{C}$. Pots were watered by drip irrigation with 20-20-20 fertilizer (Plantex, Plant Products Co. Ltd., Brampton, Ontario, Canada). Pots received $500 \mathrm{mls}$ of $0.6 \mathrm{~g} / \mathrm{l}$ fertilizer or 0.06 nitrogen units per day. Pots did not receive S. S contents of flour from grain produced under the same environmental conditions indicated that $S$ was not limiting [5]. At anthesis, pots were divided into four groups. One group of pots was left in the $24 / 17^{\circ} \mathrm{C}$ greenhouse and irrigated with fertilizer. The second group of pots was flushed with water to remove fertilizer, returned to the $24 / 17^{\circ} \mathrm{C}$ greenhouse, and hand-watered at the same rate without fertilizer. The third group of pots was transferred to a second greenhouse that had a maximum daytime temperature of $37^{\circ} \mathrm{C}$ and a minimum nighttime temperature of $28^{\circ} \mathrm{C}$ and supplied with fertilizer. The fourth group of pots was flushed with water, transferred to the $37 / 28^{\circ} \mathrm{C}$ greenhouse, and hand-watered without fertilizer. Wheat heads were harvested throughout grain fill. Grain number per head ranged from 29-49. For the $24 / 17^{\circ} \mathrm{C}$ regimens, heads were collected at 4 to 5-day intervals 
from 8 to $37 \mathrm{dpa}$. Because high temperature accelerated the grain developmental program, heads were collected at 2 to 5 -day intervals from 6 to $21 \mathrm{dpa}$ for the $37 / 28^{\circ} \mathrm{C}$ regimens. The region of the grain containing the embryo was first excised with a razor blade. The endosperm was squeezed through the resultant opening onto a spatula, leaving most of the pericarp/testa/aleurone behind. Endosperm was transferred immediately into tubes cooled in liquid nitrogen and stored at $-80^{\circ} \mathrm{C}$ $[19,48]$. For developmental studies, the end point for each regimen was the oldest age that endosperm could be squeezed or scraped from the grain after the embryo was excised. Flour was milled from mature grain samples (100 g) with a Brabender Quadrumat Junior (South Hakensack, NJ) at the Hard Winter Wheat Quality Laboratory (US Department of Agriculture, Agricultural Research Service, Manhattan, KS). Flour protein content was determined by NIR and was 7.7 for MN, 14.0 for MF, 15.9 for $\mathrm{HN}$, and 17.7 for HF [6]. Flour was stored in sealed containers at $-80^{\circ} \mathrm{C}$.

\section{Protein preparation}

A KCl-insoluble fraction enriched in gliadins and glutenin subunits was prepared from endosperm collected at each time point as described previously [48]. Fifty mg of endosperm was ground to a fine powder in liquid nitrogen using a mortar and pestle and suspended in $200 \mu$ lof cold $\left(4^{\circ} \mathrm{C}\right) \mathrm{KCl}$ buffer containing protease inhibitors (1 tablet per $10 \mathrm{ml}$ of Mini Complete Protease Inhibitor Cocktail, Roche Applied Science, Indianapolis, IN). The suspensions were incubated on ice for $5 \mathrm{~min}$ with intermittent mixing and centrifuged at $14,000 \mathrm{~g}$ for $15 \mathrm{~min}$ at $4^{\circ} \mathrm{C}$. The pellet or $\mathrm{KCl}$-insoluble fraction was suspended in $800 \mu \mathrm{l}$ of SDS buffer (2\% SDS, 10\% glycerol, $50 \mathrm{mM}$ DTT, $40 \mathrm{mM}$ Tris$\mathrm{Cl}, \mathrm{pH}$ 6.8), incubated for $1 \mathrm{~h}$ at room temperature, and insoluble material removed by centrifugation at $14,000 \mathrm{~g}$ for $10 \mathrm{~min}$ at room temperature (Eppendorf 5415C; Brinkman Instruments, Inc., Westbury, NY). Proteins were then precipitated by addition of 4 vol of cold $\left(-20^{\circ} \mathrm{C}\right)$ acetone and incubation overnight at $-20^{\circ} \mathrm{C}$ to remove SDS, which interferes with protein determination and prevents separation of proteins by IEF. Samples were centrifuged at $14,000 \mathrm{~g}$ for $10 \mathrm{~min}$ at room temperature, the pellet was rinsed by pipetting cold acetone onto the pellet, centrifuging at $14,000 \mathrm{rpm}$ for $10 \mathrm{~min}$ at room temperature, and pipetting the acetone off of the pellet. The pellet was dried at room temperature and solubilized in urea buffer ( $9 \mathrm{M}$ urea, 4\% NP-40, 1\% DTT, and 2\% ampholytes) to a final concentration of $3 \mu \mathrm{g}$ protein $/ \mu \mathrm{l}$. For protein determinations, triplicate $5 \mu \mathrm{l}$ samples were removed from the SDS extracts, precipitated with acetone, and, following addition of $0.1 \mathrm{~N} \mathrm{NaOH}$, protein amount assayed by the procedure of Lowry et al. [16] as described by Hurkman and Tanaka [49].
Flour was extracted with SDS buffer (2\% SDS, 10\% glycerol, $50 \mathrm{mM}$ DTT, $40 \mathrm{mM}$ Tris-Cl, $\mathrm{pH}$ 6.8) as described in detail by Dupont et al. [13]. Protein amounts from $50 \mathrm{mg}$ of flour from MN, MF, HN and HF treatments were determined using the Lowry assay [16] and were $3.29,5.38,6.14$ and $6.64 \mathrm{mg}$, respectively.

\section{Separation of proteins by 2-DE}

Endosperm and flour proteins were separated by 2-DE as described previously $[15,49]$. Briefly, samples were suspended in urea buffer ( $9 \mathrm{M}$ urea, $4 \% \mathrm{NP}-40,1 \% \mathrm{DTT}$, and $2 \%$ ampholytes) at a concentration of $3 \mu \mathrm{g}$ protein/ $\mu \mathrm{l}$. The first dimension capillary tube gels contained 9.2 M urea, $4 \%$ (total monomer) acrylamide:BIS, 2\% Nonidet P-40, 2\% 3-10 Iso-Dalt Grade Servalyts (Crescent Chemical Co., Islandia, NY), 0.015\% ammonium persulfate, and $0.125 \%$ TEMED. Triplicate IEF gels were loaded with $18 \mu \mathrm{g}$ of protein and run using a Mini Protean II Tube Cell (BioRad Laboratories, Richmond, CA). Gels were extruded into microcentrifuge tubes and equilibration buffer (2.3\% SDS, 10\% glycerol, $0.05 \%$ dithiothreitol, and $62.5 \mathrm{mM}$ Tris- $\mathrm{Cl}, \mathrm{pH}$ 6.8) added. The gels were frozen by placing the tubes in crushed dry ice and then stored at $-70^{\circ} \mathrm{C}$ until use. Proteins were separated in the second dimension by SDS gel electrophoresis using an XCell SureLock Mini-Cell electrophoresis system with Novex NuPage 4-12\% acrylamide BisTris gels and NuPAGE MES SDS running buffer (Invitrogen Corp., Carlsbad, CA). Gels were stained with Coomassie G-250 (Sigma, St. Louis, MO), destained in water for $2 \mathrm{~h}$ at room temperature and stored at $4^{\circ} \mathrm{C}$ in $20 \%$ ammonium sulfate.

\section{Statistical analysis of 2-D gel images}

2-DE gels were digitized with a calibrated scanner (UMAX Powerlook III; Dallas, TX) at 300 dpi using the same settings for all gels. Flour proteins were identified previously by MS/MS [13] and additional proteins in the endosperm were identified by the same methods. Progenesis SameSpots Ver. 4.0 (Nonlinear Dynamics Limited, Newcastle upon Tyne, UK) was used to detect spots, match spot patterns, normalize and quantify spot volumes, and create protein accumulation profiles. The means and standard deviations for individual spot volumes were calculated and found to be quite similar among the replicate gels for each time point. All of the gluten proteins had Anova p-values less than 0.05 and Power greater than 0.8. Progenesis SameSpots was also used to analyze 2-D gel patterns by principal component analysis and match protein accumulation patterns by correlation analysis. The spot volume data were analyzed by hierarchical cluster analysis using the TIGR MultiExperimentViewer $(\mathrm{MeV})$ v. 4.0 ([50, http://www.tm4.org/mev/]). 


\section{Additional files}

Additional file 1: Representative 2-D gels of endosperm proteins collected at specified time points for each of the growth regimens.

Additional file 2: Mass spectrometry data for newly identified wheat endosperm proteins.

Additional file 3: Normalized spot volume data for proteins extracted from developing wheat endosperm and separated by 2DE. The data are listed in the order shown in Figure 3. MN, MF, HN and HF are defined in Table 1.

Additional file 4: Normalized spot volume data for proteins extracted from wheat flour and separated by 2-DE. The data are listed in the order shown in Table 2. MN, MF, HN, and HF are defined in Table 1.

\section{Abbreviations}

2-DE: Two-dimensional gel electrophoresis; dpa: Days post-anthesis; HMWGS: High molecular weight-glutenin subunits; LMW-GS: Low molecular weight-glutenin subunits; LMW-GS : Large group of LMW-GS; LMW$\mathrm{GS}_{\mathrm{B}}$ : Small group of LMW-GS; MS/MS: Tandem mass spectrometry.

\section{Competing interests}

The authors declare that they have no competing interests.

\section{Authors' contributions}

WH was responsible for data analysis and interpretation and drafted the manuscript; CT carried out the quantitative 2-DE gel analysis and spot digestions; WV was responsible for mass spectrometry analysis and database management; RT contributed to data analysis and interpretation and manuscript editing; SA contributed to design of plant growth conditions, data analysis and interpretation, and manuscript editing. All authors read and approved the final manuscript.

\section{Acknowledgements}

This research was funded by USDA Agricultural Service CRIS Project 532543000-027-00D. Mention of trade names or commercial products in this report is solely for the purpose of providing specific information and does not imply recommendation over or endorsement by the U.S. Department of Agriculture. The U.S. Department of Agriculture is an equal opportunity provider and employer.

Received: 27 September 2012 Accepted: 31 January 2013 Published: 22 February 2013

\section{References}

1. Osborne TB: The vegetable proteins. London: Longmans, Green and Company; 1909

2. Altenbach SB: New insights into the effects of high temperature, drought and post-anthesis fertilizer on wheat grain development. J Cereal Sci 2012, 56:39-50.

3. Dupont FM, Altenbach SB: Molecular and biochemical impacts of environmental factors on wheat grain development and protein yield. $J$ Cereal Sci 2003, 38:133-146.

4. Kasarda DD, Tao HP, Evans PK, Adalsteins AE, Yuen SW: Sequencing of protein from a single spot of a 2-D gel pattern: $\mathrm{N}$-terminal sequence of a major wheat LMW glutenin subunit. J Exper Bot 1988, 39:899-906.

5. DuPont FM, Hurkman WJ, Vensel WH, Chan R, Lopez R, Tanaka CK Altenbach SB: Differential accumulation of sulfur-rich and sulfur-poor wheat flour proteins is affected by temperature and mineral nutrition during grain development. J Cereal Sci 2006, 44:101-112.

6. Dupont FM, Hurkman WJ, Vensel WH, Tanaka CK, Kothari KM, Chung OK, Altenbach SB: Protein accumulation and composition in wheat grains: effects of mineral nutrients and high temperature. Europ J Agronomy 2006, 25:96-107.

7. Grove H, Hollung K, Moldestad A, Faergestad EM, Uhlen AK: Proteome changes in wheat subjected to different nitrogen and sulfur fertilizations. J Agric Food Chem 2009, 57:4250-4258.
8. Majoul T, Bancel E, Triboi E, Ben Hamida J, Branlard G: Proteomic analysis of the effect of heat stress on hexaploid wheat grain: characterization of heatresponsive proteins from total endosperm. Proteomics 2003, 3:175-183.

9. Yang F, Jorgensen AD, Li H, Sondergaard I, Finnie C, Svensson B, Jiang D, Wollenweber B, Jacobsen S: Implications of high-temperature events and water deficits on protein profiles in wheat (Triticum aestivum L. cv. Vinjett) grain. Proteomics 2011, 11:1684-1695.

10. Zörb C, Grover C: Quantitative proteome analysis of wheat gluten as influenced by $\mathrm{N}$ and S nutrition. Plant Soil 2010, 327:225-234.

11. Zörb C, Steinfurth D, Seling S, Langenkämper G, Koehler P, Wieser $H_{\text {, }}$ Lindhauer MG, Mühling KH: Quantitative protein composition and baking quality of winter wheat as affected by late sulfur fertilization. J Agric Food Chem 2009, 57:3877-3885.

12. Vensel WH, Dupont FM, Sloane S, Altenbach SB: Effect of cleavage enzyme, search algorithm and decoy database on mass spectrometric identification of wheat gluten proteins. Phytochem 2011, 72:1154-1161.

13. Dupont FM, Vensel WH, Tanaka CK, Hurkman WJ, Altenbach SB: Deciphering the complexities of the wheat flour proteome using quantitative two-dimensional electrophoresis, three proteases and tandem mass spectrometry. Proteome Science 2011, 9:10.

14. Altenbach SB, Tanaka CK, Hurkman WJ, Vensel WH, Dupont FMD: Differential effects of a post-anthesis fertilizer regimen on the wheat flour proteome determined by quantitative 2-DE. Proteome Science 2011, 9:46.

15. Hurkman WJ, Tanaka CK: Improved methods for separation of wheat endosperm proteins and analysis by two-dimensional gel electrophoresis. J Cereal Sci 2004, 40:295-299.

16. Lowry OH, Rosebrough NJ, Farr AL, Randall RJ: Protein measurement with the Folin phenol reagent. J Biol Chem 1951, 193:265-275.

17. Hurkman WJ, McCue KF, Altenbach SB, Korn A, Tanaka CK, Kothari KM Johnson EL, Bechtel DB, Wilson JD, Anderson OD, DuPont FM: Expression of genes for starch biosynthesis is regulated by high temperature in developing wheat endosperm. Plant Sci 2003, 164:873-881.

18. Hurkman WJ, Wood D: High temperature during grain fill alters the morphology of protein and starch deposits in the starchy endosperm cells of developing wheat (Triticum aestivum L.) grain. J Agric Food Chem 2011, 59:4938-4946.

19. Hurkman WJ, Vensel WH, Tanaka CK, Whitehand L, Altenbach SB: Effect of high temperature on albumin and globulin accumulation in the endosperm proteome of the developing wheat grain. J Cereal Science 2009, 49:12-23.

20. Sung D-Y, Kaplan F, Guy CL: Plant Hsp70 chaperones: protein structure gene family, expression and function. Physiol Plant 2001, 113:443-451.

21. Jia X-Y, Xu C-Y, Jing R-L, Li R-Z, Mao X-G, Wang J-P, Chang X-P: Molecular cloning and characterization of wheat calreticulin (CRT) gene involved in drought stressed responses. J Exp Bot 2008, 59:739-751.

22. Moons A, Gielen J, Vandekerckhove J, Van Der Straeten D, Gheysen G, Van Montagu M: An abscisic-acid- and salt-stress-responsive rice cDNA from a novel plant gene family. Planta 1997, 202:443-454.

23. Bräutigam M, Lindlöf A, Zakhrabekova S, Gharti-Chhetri G, Olsson B, Olsson O: Generation and analysis of 9792 EST sequences from cold acclimated oat, Avena sativa. BMC Plant Biology 2005, 5:18.

24. Juhász A, Makai $S$, Sebestyén $E$, Tamás $L$, Balázs E: Role of conserved noncoding regulatory elements in LMW glutenin gene expression. PLOS ONE 2011, 6(12)):e29501. doi:10.1371/journal.pone.0029501.

25. Liu W, Zhang Y, Gao X, Wang K, Wang S, Zhang Y, He Z, Ma W, Yan Y: Comparative proteome analysis of glutenin synthesis and accumulation in developing grains between superior and poor quality bread wheat cultivars. J Sci Food Agric 2011, 92:106-115.

26. Colot V, Robert LS, Kavanagh TA, Bevan MW, Thompson RD: Localization of sequences in wheat endosperm protein genes which confer tissuespecific expression on tobacco. EMBO J 1987, 6:3559-3564

27. Yoshihara $\mathrm{T}$, Washida $\mathrm{H}$, Takaiwa F: A 45-bp proximal region containing AACA and GCN4 motif is sufficient to confer endosperm-specific expression of the rice storage glutelin gene, GluA-3. FEBS Lett 1996, 383:213-218.

28. Muller $\mathrm{M}$, Knudsen $\mathrm{S}$. The nitrogen response of a barley $\mathrm{C}$-hordein promoter is controlled by positive and negative regulation of the GCN4 and endosperm box. Plant J 1993, 4:343-355.

29. Shewry PR, Tatham AS, Halford NG: The Prolamins of the Triticeae. In Seed proteins. Edited by Casey R, Shewry PR. Dordrecht: Kluwer Academic Press; 1999:35-78. 
30. Daniel C, Triboi E: Effects of temperature and nitrogen nutrition on the grain composition of winter wheat: effects on gliadin content and composition. J Cereal Sci 2000, 32:45-56.

31. Wieser $\mathrm{H}$, Seilmeier $\mathrm{W}$ : The influence of nitrogen fertilizer on quantities and proportions of different protein types in wheat flour. J Sci Food Agric 1998, 76:49-55.

32. Gupta RB, Batey IL, MacRitchie F: Relationships between protein composition and functional properties of wheat flours. Cereal Chem 1992, 69:125-131.

33. Gupta RB, MacRitchie F: Biochemical basis of flour properties in bread wheats I. Effects of variation in the quantity and size distribution of polymeric protein. J Cereal Sci 1993, 18:23-41.

34. Gupta RB, Popineau Y, Lefebvre J, Cornec M, Lawrence GJ, MacRitchie F: Biochemical basis of flour properties in bread wheats II. Changes in polymeric protein formation and dough/gluten properties associated with the loss of low Mr or high Mr glutenin subunits. J Cereal Sci 1995, 21:103-116.

35. Gupta RB, Shepherd KW: Production of multiple wheat-rye 1RS translocation stocks and genetic analysis of LMW subunits of glutenin and gliadins in wheats using these stocks. Theor App/ Benet 1993, 85:719-728.

36. Irmak S, Naeem HA, Lookhart GL, MacRitchie F: Effect of heat stress on wheat proteins during kernel development in wheat near-isogenic lines differing in Glu-D1. J Cereal Sci 2008, 48:513-516.

37. MacRitchie F, Lafiandra D: Use of near-isogenic wheat lines to determine protein composition-functionality relationships. Cereal Chem 2001, 78:501-506.

38. Altenbach SB, Vensel WH, DuPont FM: Integration of transcriptomic and proteomic data from a single wheat cultivar provides new tools for understanding the roles of individual alpha gliadin proteins in flour quality and celiac disease. J Cereal Sci 2010, 52:143-151.

39. Asseng $S$, van Herwaarden AF: Analysis of the benefits to wheat yield from assimilates stored prior to grain filling in a range of environments. Plant Soil 2003, 256:217-229.

40. Barneix AJ: Physiology and biochemistry of source-regulated protein accumulation in the wheat grain. J Plant Physiol 2007, 164:581-590.

41. Ercoli L, Arduini I, Mariotti M, Masoni A: Post-anthesis dry matter and nitrogen dynamics in durum wheat as affected by nitrogen and temperature during grain filling. Cereal Res Commun 2010, 38:294-303.

42. Evans LT, Wardlaw IF: Wheat. In Photoassimilate distribution in plants and crops, source-sink relationships. Edited by Zamski E, Schaffer AA. New York: Marcel Dekker, Inc; 1996:501-518.

43. Gebbing T, Schnyder H, Kübauch W: The utilization of pre-anthesis reserves in grain filling of wheat. Assessment by steady-state 13C02/ 12C02 labeling. Plant Cell Environ 1999, 22:851-858.

44. Jenner CF, Ugalde TD, Aspinall D: The physiology of starch and protein deposition in the endosperm of wheat. Aust J Plant Physiol 1991, 18:211-226.

45. Schnyder $\mathrm{H}$ : The role of carbohydrate storage and redistribution in the source-sink relations of wheat and barley during grain filling - a review. New Phytol 1993, 123:233-245.

46. Altenbach SB, Allen PV: Transformation of the US bread wheat 'Butte $86^{\prime}$ and silencing of omega-5 gliadin genes. GM Crops 2011, 2:67-73.

47. Altenbach SB, DuPont FM, Kothari KM, Chan R, Johnson EL, Lieu D: Temperature, water and fertilizer influence the timing of key events during grain development in a US spring wheat. J Cereal Sci 2003, 37:9-20.

48. Vensel WH, Tanaka CK, Cai N, Wong JH, Buchanan BB, Hurkman WJ: Developmental changes in the metabolic protein profiles of wheat endosperm. Proteomics 2005, 5:1594-1611.

49. Hurkman WJ, Tanaka CK: Extraction of wheat endosperm proteins for proteome analysis. J Chromatography B 2007, 849:344-350.

50. Saeed Al, Sharov V, White J, Li J, Liang W, Bhagabati N, Braisted J, Klapa M, Currier T, Thiagarajan M, Sturn A, Snuffin M, Rezantsev A, Popov D, Ryltsov A, Kostukovich E, Borisovsky I, Liu Z, Vinsavich A, Trush V, Quackenbush J: TM4: a free, open-source system for microarray data management and analysis. Biotechniques 2003, 34:374-8.

doi:10.1186/1477-5956-11-8

Cite this article as: Hurkman et al:: Comparative proteomic analysis of the effect of temperature and fertilizer on gliadin and glutenin accumulation in the developing endosperm and flour from Triticum aestivum L. cv. Butte 86. Proteome Science 2013 11:8.

\section{Submit your next manuscript to BioMed Central and take full advantage of:}

- Convenient online submission

- Thorough peer review

- No space constraints or color figure charges

- Immediate publication on acceptance

- Inclusion in PubMed, CAS, Scopus and Google Scholar

- Research which is freely available for redistribution

Submit your manuscript at www.biomedcentral.com/submit
() Biomed Central 